\title{
PENGARUH EQUIVALENT RATE, PROFITABILITAS, DAN JUMLAH KANTOR TERHADAP DANA PIHAK KETIGA BPRS DI INDONESIA (Periode Tahun 2013-2015)1]
}

\author{
Almira Ulfa Nugraheni \\ Mahasiswa Progam Studi S1 Ekonomi Islam - Fakultas ekonomi dan Bisnis - Universitas Airlangga \\ Email: almira-12@feb.unair.ac.id \\ Dina Fitrisia Septiarini \\ Departemen Ekonomi Syariah - Fakultas Ekonomi dan Bisnis - Universitas Airlangga \\ Email: dina.fitrisia@feb.unair.ac.id
}

\begin{abstract}
:
This study aims to determine the effect equivalent rate, profitability and the number of offices to Third Party Funds of Sharia Rural Banks in Indonesia in 2013 until 2015. The research method used is a quantitative approach. The dependent variable in this study is the Third Party Funds, as well as the independent variable in this study is equivalent rate, the rate of profit and the number of offices. Sample used is a saturated sampling and used multiple linear regression as analytical technique.

Research results shows that the confidence level is $95 \%$, equivalent rate, profitability, and the number of office have a significant effect on the magnitude of the amount of third party funds Sharia Rural Banks in Indonesia with $81.1 \%$ integration level. The partially, only the rate of profit and the number of office that significantly influence the large number of Sharia Rural banks in Indonesia.
\end{abstract}

Keywords: Equivalent rate, Profit Rate, Number of Offices, Third Party Fund, Sharia Rural Bank

\section{PENDAHULUAN}

\section{Latar Belakang}

Bank secara umum dikenal sebagai lembaga dalam bidang keuangan yang memiliki tiga fungsi utama yaitu menerima simpanan vang, meminjamkan vang, dan memberikan jasa pengiriman vang (Karim, 2004:18). Sementara Bank Syariah adalah bank yang beroperasi sesuai dengan prinsip-prinsip Islam yakni bank dengan tatacara dan operasinya mengikuti ketentuan-ketentuan syariah. Bank syariah didirikan dengan tujuan untuk mempromosikan dan mengembangkan penerapan prinsip-prinsip Islam, syariah, dan tradisinya kedalam transaksi keuangan dan perbankan serta bisnis lain yang terkait.
Salah satu prinsip utama yang ada di bank syariah adalah adanya pelarangan riba (Arifin, 2002:12). Dalam Undang-undang No. 21 tahun 2008 pasal 1 disebutkan bahwa Perbankan Syariah terdiri berdasarkan tiga prinsip yaitu, Bank Umum Syariah, Bank Pembiayaan Rakyat Syariah, dan Unit Usaha Syariah. Dewasa ini masyarakat di Indonesia mulai menyadari bahwasannya praktik riba dalam Islam sangatlah dilarang, larangan riba telah diatur oleh Allah SWT dalam beberapa surat dan ayat, termasuk dalam surat Al Baqarah ayat 198 sebagai berikut:

1) Jurnal ini merupakan bagian dari skripsi dari Almira Ulfa Nugraheni. NIM 041211433088 yang diuji pada 23 Januari 2017 
Nugraheni, et al/Jurnal Ekonomi Syariah Teori dan Terapan Vol. 4 No. 11 November 2017: 875-888; PENGARUH EQUIVALENT RATE, PROFITABILITAS, DAN JUMLAH KANTOR TERHADAP DANA PIHAK KETIGA BPRS DI INDONESIA (PERIODE TAHUN 2013-2015)

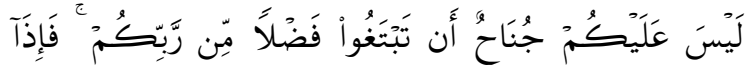

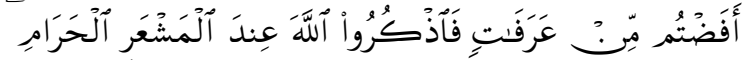
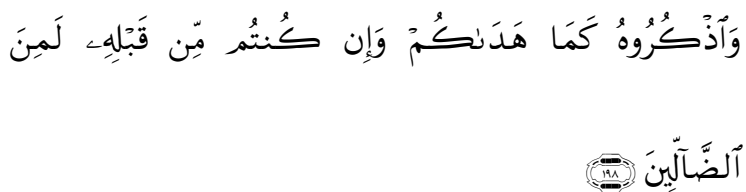

Laisa 'alaikum junāḥun an tabtagū fadlam mir rabbikum, fa iżā afadtum min 'Arafātin fażkurullāha imdal-masy'ari-haram, ważkuruhu kamā hadākum, wa in kuntum min qablihi laminad-dāllin.

"Tidak ada dosa bagimu untuk mencari karunia (rezeki hasil perniagaan) dari Tuhanmu. Maka apabila kamu telah bertolak dari "Arafah, berzikirlah (dengan menyebut) Allah sebagaimana yang ditunjukkan Nya kepadamu; dan sesungguhnya kamu sebelum itu benarbenar termasuk orang yang sesat" (Departemen Agama RI, Al-Qur'an Tajwid dan terjemahan 2010)

Berbeda dengan Bank Umum Syariah, Bank Pembiayaan Rakyat Syariah merupakan bank yang bersinggungan secara langsung terhadap masyarakat khususnya masyarakat menengah. Tujuan operasional BPR Syariah yaitu meningkatkan ekonomi umat Islam terutama masyarakat lemah yang ada di pedesaan, menambah lapangan kerja terutama di kecamatan sehingga dapat mengurangi arus urbanisasi, serta membina ukhuwah islamiyah melalui kegiatan ekonomi dalam rangka peningkatan pendapatan per kapita menuju kualitas hidup yang memadai (Sumitro, 2004:129-130). Nasabah akan membandingkan secara cermat antara expected rate of return yang ditawarkan bank syariah dengan tingkat suku bunga yang ditawarkan oleh bank konvensional. Terdapat perbedaan antara bagi hasil dengan equivalent rate. Pada nisbah bagi hasil, nasabah dapat memperkirakan besarnya pembagian hasil tiap bulannya dengan pembagian 60:40, sementara penyebutan equivalent rate hanya untuk mempermudah nasabah dalam bagi hasil, bukan bagi hasilnya (Susanti, 2015).

Selain equivalent rate nisbah bagi hasil, terdapat tingkat keuntungan yang juga ikut mempengaruhi masyarakat untuk menjadi nasabah pada sebuah bank. Apabila sebuah bank memiliki tingkat keuntungan yang tinggi, maka akan cenderung timbul kepercayaan dalam masyrakat untuk menginvestasikan uangnya (dalam bentuk tabungan) pada bank tersebut (Susanti, 2015).

Jumlah kantor BPR Syariah di Indonesia terus mengalami peningkatan setiap tahunnya, hingga pada Desember tahun 2015 tercata bahwa ada 446 unit jumlah kantor BPR Syariah di Indonesia. Hingga April 2016 jumlah bank syariah di Indonesia berjumlah 199 bank syariah yang terdiri dari 12 Bank Umum Syariah (BUS), 22 Unit Usaha Syariah (UUS), dan 165 Bank 
Nugraheni, et al/Jurnal Ekonomi Syariah Teori dan Terapan Vol. 4 No. 11 November 2017: 875-888; PENGARUH EQUIVALENT RATE, PROFITABILITAS, DAN JUMLAH KANTOR TERHADAP DANA PIHAK KETIGA BPRS DI INDONESIA (PERIODE TAHUN 2013-2015)

Pembiayaan Rakyat Syariah (BPRS)

(akuntansikeuangan.com).

Pertumbuhan DPK pada BPR Syariah didorong dari pertumbuhan simpanan wadiah dan deposito mudharabah. Simpanan wadiah tumbuh $22,93 \%$ dari Rp 781 Miliar pada bulan Februari 2015 menjadi Rp 960 Miliar pada bulan Februari 2016. Deposito mudharabah tumbuh 20,04\% dari Rp 2,51 triliun menjadi Rp 3,06 triliun. Sementara simapanan mudharabah tumbuh sebesar 14,84\% dari Rp 749 miliar menjadi Rp860 miliar. Komposisi terbesar dana di BPR Syariah masih di kontribusi oleh Deposito mudharabah dengan porsi mencapai $62,73 \%$, diikuti oleh simpanan wadiah $19,60 \%$ dan simpanan mudharabah $17,61 \%$ (infobanknews.com).

Equivalent rate, profitabilitas dan jumlah kantor merupakan fator internal yang mempengaruhi besarnya DPK dari segi kinerja keuangan dan layanan. Berdasarkan penjelasan tersebut, maka penelitian ini memiliki judul "Pengaruh Equivalent Rate, Profitabilitas, dan Jumlah Kantor Terhadap Dana Pihak Ketiga (DPK) BPR Syariah di Indonesia (Periode 20132015)".

\section{Rumusan Masalah}

Setelah melihat uraian yang ada dalam latar belakang masalah, maka dapat dikemukakan rumusan masalah sebagai berikut :

1. Apakah equivalent rate, profitabilitas, dan jumlah kantor

berpengaruh terhadap dana pihak ketiga (DPK) pada BPR Syariah di Indonesia secara simultan?

2. Apakah equivalent rate bagi hasil tabungan berpengaruh terhadap dana pihak ketiga (DPK) pada BPR Syariah di Indonesia secara parsial?

3. Apakah profitabilitas berpengaruh terhadap dana pihak ketiga (DPK) pada BPR Syariah di Indonesia secara parsial?

4. Apakah jumlah kantor berpengaruh terhadap dana pihak ketiga (DPK) pada BPR Syariah di Indonesia secara parsial?

\section{Tujuan Penelitian}

1. Untuk mengetahui pengaruh equivalent rate, profitabilitas, dan jumlah kantor terhadap dana pihak ketiga (DPK) pada BPR Syariah di Indonesia secara simultan.

2. Untuk mengetahui pengaruh equivalent rate bagi hasil tabungan terhadap dana pihak ketiga (DPK) pada BPR Syariah di Indonesia secara parsial.

3. Untuk mengetahui pengaruh profitabilitas terhdap dana pihak ketiga (DPK) pada BPR Syariah di Indonesia secara parsial.

4. Untuk mengetahui pengaruh jumlah kantor terhadap dana pihak ketiga (DPK) pada BPR Syariah di Indonesia secara parsial. 
Nugraheni, et al/Jurnal Ekonomi Syariah Teori dan Terapan Vol. 4 No. 11 November 2017: 875-888; PENGARUH EQUIVALENT RATE, PROFITABILITAS, DAN JUMLAH KANTOR TERHADAP DANA PIHAK KETIGA BPRS DI INDONESIA (PERIODE TAHUN 2013-2015)

\section{TINJAUAN PUSTAKA}

\section{Bank}

Menurut Undang-Undang RI nomor 10 Tahun 1998 yang dimaksud dengan Bank adalah badan usaha yang menghimpun dana dari masyarakat dalam bentuk simpanan dan menyalurkannya kepada masayarakat dalam bentuk kredit dan atau bentuk-bentuk lainnya dalam rangka meningkatkan taraf hidup rakyat banyak.

\section{Perbankan Syariah}

Dalam Undang-undang No. 21 tahun 2008 pasal 1 disebutkan bahwa Perbankan Syariah terdiri berdasarkan tiga prinsip yaitu, Bank Umum Syariah, Bank Pembiayaan Rakyat Syariah, dan Unit Usaha Syariah.

BPRS berdiri berdasarkan UU No. 7 Tahun 1992 tentang Perbankan dan Peraturan Pemerintah (PP) No. 72 Tahun 1992 tentang Bank Berdasarkan Prinsip Bagi Hasil. Pada pasal 1 (butir 4) UU No. 10 Tahun 1998 tentang Perubahan atas UU No. 7 Tahun 1992 tentang Perbankan, disebutkan bahwa BPRS adalah bank yang melaksanakan kegiatan usaha berdasarkan prinsip syariah yang dalam kegiatannya tidak memberikan jasa dalam lalu lintas pembayaran.

\section{Equivalent Rate}

Menurut Antonio (2001:160) equivalent rate bagi hasil tabungan adalah jumlah bagi hasil untuk seorang nasabah perbulan dibagi dengan saldo rata-rata tabungan nasabah tersebut yang dinyatakan dalam bentuk persentase. Equivalent rate merupakan tambahan atau tingkat imbalan untuk nasabah penyimpan dari suatu penanaman atau investasi dana yang berikan oleh bank. Equivalent rate dapat diartikan juga sebagai tingkat pengembalian atas investasi yang telah ditanamkan. Berbeda dengan bunga yang langsung diperjanjikan diawal kontrak sebelum investasi berjalan oleh bank, equivalent rate dihitung oleh bank setiap akhir bulan setelah investasi yang dijalankan memberikan hasil. Nasabah dapat memperkirakan equivalent rate bank yang sedang berjalan berdasarkan ekuivalen rate yang diterima atau diberikan oleh bank pada bulan sebelumnya (Susanti, 2015).

\section{Profitabilitas}

Menurut Muhammad (2004: 159) rasio profitabilitas adalah rasio yang menunjukkan tingkat efektivitas yang dicapai melalui usaha operasional bank. Terdapat beberapa jenis rasio keuangan, diantaranya adalah Gross Profit Margin (GPM), Net Profit Margin (NPM), Operatin Ratio, Return On Asset (ROA), Return On Equity (ROE).

\section{Jumlah Kantor}

Menurut Moekijat (1997:3), kantor adalah setiap tempat yang biasanya dipergunakan untuk melaksanakan pekerjaan tata usaha, dengan nama 
Nugraheni, et al/Jurnal Ekonomi Syariah Teori dan Terapan Vol. 4 No. 11 November 2017: 875-888; PENGARUH EQUIVALENT RATE, PROFITABILITAS, DAN JUMLAH KANTOR TERHADAP DANA PIHAK KETIGA BPRS DI INDONESIA (PERIODE TAHUN 2013-2015)

apapun juga tempat tersebut mungkin diberikan. Menurut Kamus Besar Bahasa Indonesia kantor adalah balai (gedung, rumah, ruang) tempat mengurus suatu pekerjaan atau juga disebut tempat bekerja. Jenis-jenis kantor bank menurut Kasmir (2010: 48) adalah kantor pusat, kantor cabang penuh, kantor cabang pembantu, dan kantor kas.

\section{Dana Pihak Ketiga}

Dana pihak ketiga merupakan dana yang dihimpun oleh bank syariah, sumber dana berasal dari modal inti (core capital), dana pihak ketiga yang terdiri dari dana titipan (wadiah), dan kuasi ekuitas (mudharabah) (Machmud, 2009:79). Dana pihak ketiga adalah dana yang diperoleh bank yang bersumber dari pihak masyarakat yang menanamkan atau menitipkan uangnya (dana) kepada pihak bank. Dana dari masyarakat yang disimpan didalam bank merupakan dana yang paling diandalkan bank untuk direalisasikan kembali kepada masyarakat yang membutuhkan pinjaman (Antonio, 2011).

\section{Hubungan antar variabel}

1. Arafah (2015) BI rate, inflasi, pertumbuhan ekonomi, equivalent rate, biaya promosi, dan bonus wadiah secara simultan berpengaruh signifikan terhadap Dana Pihak Ketiga (DPK) bank syariah di Indonesia. Artinya apabila $\mathrm{Bl}$ rate, inflasi, pertumbuhan ekonomi, equivalent rate, biaya promosi dan bonus wadiah perbankan syariah naik maka jumlah dana pihak ketiga perbankan syariah juga akan ikut naik.

2. Giannini (2013) hasil perhitungan dari variabel tingkat bagi hasil menunjukkan bahwa secara parsial tingkat bagi hasil berpengaruh positif signifikan terhadap pembiayaan mudharabah yang ditunjukkan dengan besarnya koefisien regresi sebesar 0,488 dan tingkat signifikansi yang kurang dari 0,05 yaitu 0,001. Berarti hipotesis yang menyatakan bahwa rasio tingkat bagi hasil berpengaruh positif terhadap pembiayaan mudharabah adalah diterima.

3. Susanti (2015) mengatakan bahwa tingkat keuntungan berpengaruh positif dan signifikan terhadap DPK perbankan syariah di Indonesia. Artinya apabila tingkat keuntungan perbankan syariah juga akan ikut naik.

4. Wardani (2015) dalam penelitiannya menyatakan bahwa jaringan kantor memiliki pengaruh yang positif terhadap giro perbankan syariah karena perluasan jaringan Perbankan Syariah berhasil menarik nasabah baru dalam jumlah signifikan. Artinya, apabila jaringan kantor naik maka jumlah Dana Pihak 
Nugraheni, et al/Jurnal Ekonomi Syariah Teori dan Terapan Vol. 4 No. 11 November 2017: 875-888; PENGARUH EQUIVALENT RATE, PROFITABILITAS, DAN JUMLAH KANTOR TERHADAP DANA PIHAK KETIGA BPRS DI INDONESIA (PERIODE TAHUN 2013-2015)

Ketiga perbankan syariah juga ikut naik.

\section{Hipotesis}

Dalam penelitian ini, diajukan hipotesis sebagai berikut:

$\mathrm{H}_{1}=$ Equivalent rate, profitabilitas, dan jumlah kantor secara bersasama-sama (simultan) memiliki pengaruh yang signifikan terhadap dana pihak ketiga pada BPR Syariah di Indonesia periode 2013-2015.

$\mathrm{H}_{2}=$ Equivalent rate secara parsial memiliki pengaruh yang signifikan terhadap dana pihak ketiga pada BPR Syariah di Indonesia pada periode 2013-2015.

$\mathrm{H}_{3}=$ Profitabilitas secara parsial memiliki pengaruh yang signifikan terhadap dana pihak ketiga pada BPR Syariah di Indonesia pada periode 2013-2015.

$\mathrm{H}_{4}=$ Jumlah kantor secara parsial memiliki pengaruh yang signifikan terhadap dana pihak ketiga pada BPR Syariah di Indonesia periode 2013-2015.

\section{Model Analisis}

Model analisis dalam penelitian ini dapat digambarkan sebagai berikut:

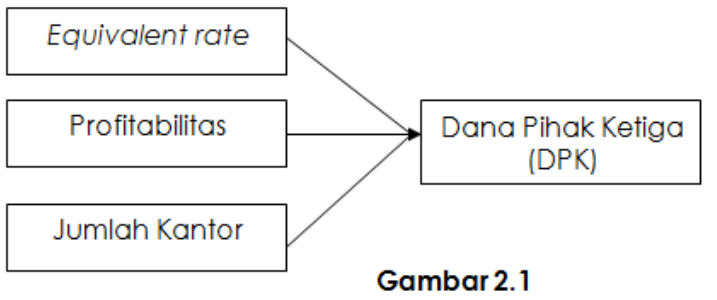

Model Analisis Secara Parsia

Sumber: data diolah

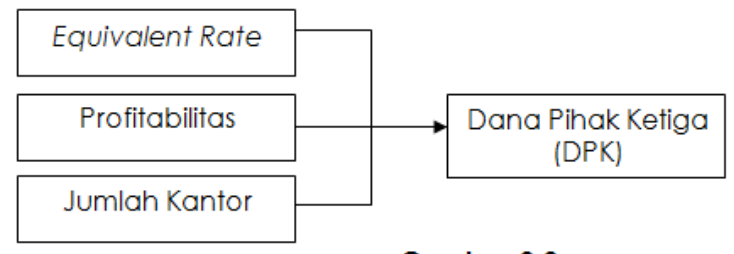

Gambar 2.2

Model Analisis Secara Simultan

Sumber: data diolah

III. Metode Penelitian

Pendekatan Penelitian

Penelitian ini menggunakan pendekatan kuantitatif. Sugiyono (2012:13) menarik kesimpulan sebagai berikut, metode penelitian kuantitatif dapat diartikan sebagai metode penelitian yang berlandaskan pada filsafat posotovis, digunakan untuk meneliti pada populasi atau sampel tertentu, pengumpulan data menggunakan instrument penelitian, analisis data bersifat kuntitatif/sttistik dangan tujuan untuk menguji hipotesis yang telah ditetapkan. Teknik analisis yang digunakan untuk mengetahui hubungan antar variabel menggunakan regresi linier berganda. Adapun program statistik yang digunakan untuk mempermudah dalam pengolahan data menggunakan program SPSS 16.0.

\section{Identifikasi Variabel}

Variabel yang digunakan dalam penelitian ini terdiri dari dua jenis, yakni variabel independen dan variabel dependen. Variabel independen adalah variabel bebas yang mempengeruhi variabel terikat/dependen. Adapun 
Nugraheni, et al/Jurnal Ekonomi Syariah Teori dan Terapan Vol. 4 No. 11 November 2017: 875-888; PENGARUH EQUIVALENT RATE, PROFITABILITAS, DAN JUMLAH KANTOR TERHADAP DANA PIHAK KETIGA BPRS DI INDONESIA (PERIODE TAHUN 2013-2015)

variabel independen dalam penelitian ini adalah equivalent rate, profitabilitas, dan jumlah kantor. Varibel dependen adalah variabel terikat yang perubahannya dipengaruhi oleh varibel bebas / independen, dalam penelitian ini variabel dependen yan digunakan adalah Dana Pihak Ketiga BPR Syariah di Indonesia.

\section{Definisi Operasional Variabel}

1. Equivalent rate

Equivalent rate merupakan tambahan atau tingkat imbalan untuk nasabah penyimpan dari suatu penanaman atau investasi dana yang berikan oleh bank. Dalam penelitian ini, rata-rata seluruh equivalent rate yang digunakan adalah equivalent rate pada Industri BPR Syariah Indonesia pada tahun 2013-2015 yang diambil setiap bulan dimana data yang diambil tersebut merupakan data rasio.

2. Profitabilitas

Profitabilitas adalah jumlah keuntungan yang diperoleh oleh bank (perbank syariah) yang dinyatakan dalam bentuk nominal Rupiah yang merupakan akibat dari kegiatan usaha yang dilakukan baik dalam bentuk pembiayaan ataupun kegiatan jasa lainnya (Susanti:2015). Dalam penelitian ini, profitabilitas yang digunakan adalah laba bersih setelah pajak pada Industri BPR
Syariah Indonesia pada tahun 20132015 yang diambil setiap bulan.

3. Jumlah Kantor Menurut Moekijat (1997:3), kantor adalah setiap tempat yang biasanya dipergunakan untuk melaksanakan pekerjaan tata usaha, dengan nama apapun juga tempat tersebut mungkin diberikan. Dalam penelitian ini, data jumlah kantor Industri BPR Syariah statistik perbankan syariah yang terdapat di website OJK dari tahun 2013-2015 yang diambil setiap bulan dimana data tersebut nantinya diubah dengan menggunakan metode logaritma natural agar tidak terjadi selisih satuan dan untuk mengurangi tingkat kesalahan dalam hasil penelitian.

4. Dana Pihak Ketiga

Dana pihak ketiga adalah dana yang diperoleh bank yang bersumber dari pihak masyarakat yang menanamkan atau menitipkan vangnya (dana) kepada pihak bank. Dalam penelitian ini, dana pihak ketiga yang digunakan adalah Dana Pihak Ketiga pada Industri BPR Syariah statistik perbankan syariah yang terdapat di website OJK dari tahun 2013-2015 yang diambil setiap bulan sekali dimana data tersebut nantinya diubah dengan menggunakan 
Nugraheni, et al/Jurnal Ekonomi Syariah Teori dan Terapan Vol. 4 No. 11 November 2017: 875-888; PENGARUH EQUIVALENT RATE, PROFITABILITAS, DAN JUMLAH KANTOR TERHADAP DANA PIHAK KETIGA BPRS DI INDONESIA (PERIODE TAHUN 2013-2015)

metode logaritma natural agar tidak terjadi selisih satuan dan untuk mengurangi tingkat kesalahan dalam hasil penelitian.

\section{Prosedur Pengumpulan Data}

Prosedur pengumpulan data yang dilakukan peneliti adalah sebagai berikut:

1. Metode pengumpulan data tidak langsung

Dilakukan dengan mengumpulkan data penelitian yang bersumber dari data sekunder, yaitu laporan keuangan bulanan BPR Syariah di Indonesia pada periode Januari 2013 hingga Desember 2015 yang terdapat dalam website OJK pada statistik perbankan syariah (SPS).

2. Studi kepustakaan

Dilakukan dengan mengumpulkan dan mempelajari berbagai jurnal, buku pustaka, artikel, dan bahan-bahan lain yang digunakan untuk memahami permasalahan dan mendapatkan alternatif pemecahan masalah yang ada.

\section{Teknik Analisis Data}

Teknik analisis yang digunakan dalam penelitian ini adalah regresi linier berganda, proses perhitungannya dalam penelitian ini menggunakan program SPSS (Statistical Program for Social Science) versi 16.0. Tujuan dari analisis regresi berganda adalah menggunakan nilai-nilai variabel bebas yang diketahui untuk meramalkan nilai variabel tergantung.

\section{Uji Asumsi Klasik}

Metode analisis yang digunakan dalam penelitian ini adalah analisis regresi linier berganda. Analisis regresi linier berganda bertujuan untuk memperoleh gambaran yang menyeluruh mengenai hubungan antara variabel independen dan variabel dependen. Sebelum melakukan uji linier berganda, metode mensyaratkan untuk melakukan uji asumsi klasik agar mendapatkan hasil yang terbaik (Ghozali, 2011:105). Uji asumsi dasar tersebut diantaranya, uji normalitas, uji autokolerasi, uji heterokedastisitas, dan uji multikolinieritas. Sedangkan uji regresi meliputi uji F, uji t, dan koefisien determinasi berganda $\left(R^{2}\right)$.

\section{HASIL DAN PEMBAHASAN}

\section{Uji Normalitas}

Uji normalitas bertujuan untuk menguji apakah dalam model regresi, variabel pengganggu atau residual memiliki distribusi normal. Metode yang digunakan dengan analisis grafik dan uji statistik. Dalam analisis grafik, distribusi normal akan membentuk satu garis lurus diagonal dan ploting data residual akan dibandingkan dengan garis diagonal tersebut (Ghozali, 201 1:160).

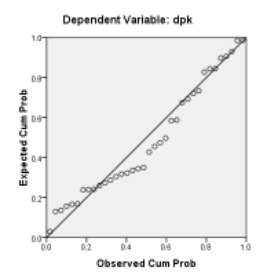

Gambar 1 
Nugraheni, et al/Jurnal Ekonomi Syariah Teori dan Terapan Vol. 4 No. 11 November 2017: 875-888; PENGARUH EQUIVALENT RATE, PROFITABILITAS, DAN JUMLAH KANTOR TERHADAP DANA PIHAK KETIGA BPRS DI INDONESIA (PERIODE TAHUN 2013-2015)

\section{Hasil Uji Normalitas}

\section{Uji Autokolerasi}

Uji autokorelasi bertujuan untuk menguji adanya korelasi antara periode † dengan periode t-1 (sebelumnya) dalam model regresi linier. Jika terjadi korelasi, maka dinamakan ada problem autokorelasi (Ghozali, 2011:110).

\section{Tabel 1}

Hasil Uji Autokolerasi

\begin{tabular}{|l|c|r|r|r|r|}
\hline \begin{tabular}{|l|l|l|l|}
\hline Mod \\
$\mathrm{el}$
\end{tabular} & $\mathrm{R}$ & $\mathrm{R}$ & $\begin{array}{c}\text { Adjusted R } \\
\text { Square }\end{array}$ & $\begin{array}{c}\text { Std. Error of } \\
\text { the } \\
\text { Estimate }\end{array}$ & $\begin{array}{c}\text { Durbin- } \\
\text { Watson }\end{array}$ \\
\hline 1 & $.910^{\circ}$ & .827 & .811 & .05236 & .759 \\
\hline
\end{tabular}

Berdasarkan output pada tabel 1, diketahui model regresi adalah 0,759 sedangkan tabel DW dengan signifikan 0,005 dan jumlah data $(n)=36$ serta $k=3(k$ adalah jumlah variabel independen diperoleh nilai dl sebesar 1,098 dan dU sebesar 1,442, karena nilai DW pada penelitian ini sebesar 0,759 < dari 4-da atau 4-1,1442 yang bernilai 2,558 maka dapat disimpulkan bahwa tidak adanya kolerasi antara variabel dalam penelitian ini.

\section{Uji Heterokedastisitas}

Uji heteroskedastisitas bertujuan untuk menguji ketidaksamaan varian dari residual satu pengamatan ke pengamatan yang lain. Model regresi yang baik adalah yang homoskedastisitas atau tidak terjadi heteroskedastisitas (Ghozali, 2011:139).

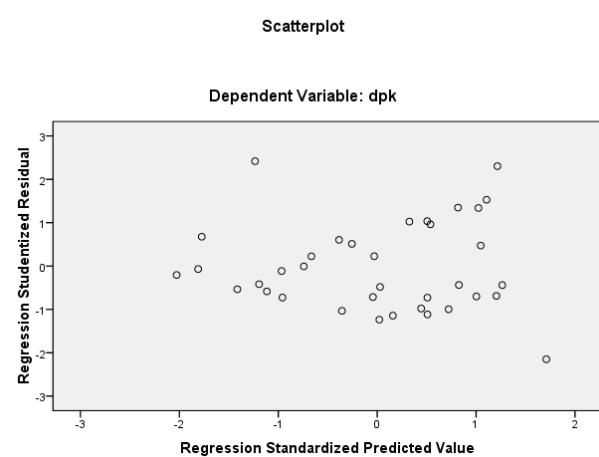

\section{Gambar 2} Hasil Uji Heterokedastisitas

Uji Multikolinieritas

Uji multikolinieritas bertujuan untuk menguji apakah model regresi ditemukan adanya korelasi antar variabel bebas atau independen (Ghozali, 2011 1:105).

\section{Tabel 2}

\section{Hasil Uji Multikolinieritas}

\begin{tabular}{|c|c|c|c|c|c|c|c|c|}
\hline \multicolumn{9}{|c|}{ Coefficients ${ }^{\circ}$} \\
\hline & & \multicolumn{2}{|c|}{$\begin{array}{l}\text { Unstandardized } \\
\text { Coefficients }\end{array}$} & \multirow{2}{*}{\begin{tabular}{|c|}
$\begin{array}{c}\text { Standardized } \\
\text { Coefficients }\end{array}$ \\
Beta \\
\end{tabular}} & \multirow[b]{2}{*}{$t$} & \multirow[b]{2}{*}{ Sig. } & \multicolumn{2}{|c|}{$\begin{array}{c}\text { Collinearity } \\
\text { Statistics }\end{array}$} \\
\hline \multicolumn{2}{|c|}{ Model } & B & Std. Error & & & & $\begin{array}{c}\text { Toleranc } \\
e\end{array}$ & VIF \\
\hline 1 & $\begin{array}{l}\text { (Constan } \\
\text { (t) }\end{array}$ & 16.491 & 1.016 & & 16.233 & .000 & & \\
\hline & er & .007 & .006 & .082 & 1.073 & .291 & .935 & 1.070 \\
\hline & tp & .058 & .011 & .385 & 5.076 & .000 & .939 & 1.065 \\
\hline & jk & 1.811 & .159 & .840 & 11.377 & .000 & .991 & 1.009 \\
\hline
\end{tabular}

Berdasarkan output pada tabel 2 diketahui bahwa nilai tolerance equivalent rate (ER) sebagai $X_{1}$, tingkat profitabilitas (TP) sebagai $X_{2}$, dan jumlah kantor (JK) sebagai $X_{3}$ lebih besar dari 0,1 yaitu sebesar 0,935; 0,939; dan 0,991. Dan nilai VIF variabel $\mathrm{X}_{1}, \mathrm{X}_{2}$, dan $\mathrm{X}_{3}$ lebih kecil dari 10 yaitu sebesar $\mathrm{X}_{1}: 1,070 \mathrm{X}_{2}: 1,065$ dan $\mathrm{X}_{3}: 1,009$. Dari hasil tersebut dapat disimpulkan bahwa tidak ada multikolinieritas antar variabel independen dalam model regresi. 
Nugraheni, et al/Jurnal Ekonomi Syariah Teori dan Terapan Vol. 4 No. 11 November 2017: 875-888; PENGARUH EQUIVALENT RATE, PROFITABILITAS, DAN JUMLAH KANTOR TERHADAP DANA PIHAK KETIGA BPRS DI INDONESIA (PERIODE TAHUN 2013-2015)

\section{Analisis Regresi Linier Berganda dan Uji Hipotesis}

Tabel 3

Hasil Analisis Regresi Berganda

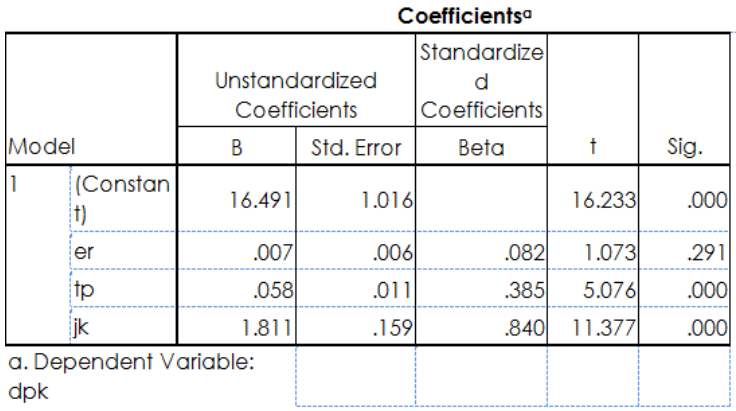

Berdasarkan hasil analisis regresi berganda pada tabel 3 diperoleh koefisien untuk variabel bebas $E R=0,007, \mathrm{TP}=0,058$, $\mathrm{JK}=1,811$ dengan konstanta sebesar 16,491 sehingga model persamaan regresi yang diperoleh adalah:

DPK $=16,491+0,007 \mathrm{ER}+0,023 \mathrm{TP}+1,811 \mathrm{JK}$

Uji $\mathbf{F}$

Menurut Ghozali (2011:98), uji statistik F pada dasarnya menunjukkan apakah semua variabel independen atau bebas yang dimasukkan dalam model mempunyai pengaruh secara bersama-sama terhadap variabel dependen atau terikat.

\section{Tabel 4}

\section{Hasil Uji F}

\begin{tabular}{|c|c|c|c|c|c|c|}
\hline \multicolumn{7}{|c|}{ ANOVAb $^{b}$} \\
\hline \multicolumn{2}{|c|}{ Model } & $\begin{array}{l}\text { Sum of } \\
\text { Squares }\end{array}$ & df & $\begin{array}{c}\text { Mean } \\
\text { Square }\end{array}$ & $\mathrm{F}$ & Sig. \\
\hline \multirow[t]{3}{*}{1} & $\begin{array}{c}\text { Regressio } \\
n\end{array}$ & .420 & 3 & .140 & 51.061 & $.000^{\circ}$ \\
\hline & Residual & .088 & 32 & .003 & & \\
\hline & Total & .508 & 35 & & & \\
\hline \multicolumn{4}{|c|}{ a. Predictors: (C } & & & \\
\hline
\end{tabular}

Pada tabel 4 hasil perhitungan dengan menggunakan program SPSS diketahui bahwa nilai Fhitung sebesar 51,061.
Nilai Ftabel dalam penelitian ini dengan signifikansi 0,05 diperoleh hasil sebesar 2,90. Dalam penelitian ini diperoleh hasil bahwa Ftabel $2,90<$ Fhitung 51,0661 maka dapat disimpulkan bahwa $\mathrm{H}_{1}$ diterima atau bahwa terdapat pengaruh yang signifikan antara equivalent rate (ER), tingkat profitabilitas (TP), dan jumlah kantor (JK) terdahap dana pihak ketiga (DPK) secara simultan.

Uji $\uparrow$

Uji $†$ bertujuan untuk mengetahui apakah variabel independen secara parsial (sendiri) berpengaruh signifikan terhadap variabel dependen Ghozali (2011:98). Uji † digunakan untuk menemukan pengaruh yang paling dominan antara masingmasing variabel independen untuk menjelaskan variasi variabel dengan tingkat keyakinan (level of significance) sebesar $95 \%$ atau $a=5 \%$.

Tabel 5

Hasil Uji $\dagger$

\begin{tabular}{|c|c|c|c|c|c|c|c|c|}
\hline \multicolumn{9}{|c|}{ Coefficients } \\
\hline & & \multicolumn{2}{|c|}{$\begin{array}{l}\text { Unstandardized } \\
\text { Coefficients }\end{array}$} & \multirow{2}{*}{\begin{tabular}{|c|}
$\begin{array}{c}\text { Standardized } \\
\text { Coefficients }\end{array}$ \\
Beta \\
\end{tabular}} & \multirow[b]{2}{*}{$t$} & \multirow[b]{2}{*}{ Sig. } & \multicolumn{2}{|c|}{$\begin{array}{l}\text { Collinearity } \\
\text { Statistics }\end{array}$} \\
\hline \multicolumn{2}{|c|}{ Model } & B & Std. Error & & & & Tolerance & VIF \\
\hline \multirow[t]{4}{*}{1} & (Constant) & 16.491 & 1.016 & & 16.233 & .000 & & \\
\hline & er & .007 & .006 & .082 & 1.073 & .291 & .935 & 1.070 \\
\hline & tp & .058 & .011 & .385 & 5.076 & .000 & .939 & 1.065 \\
\hline & $\mathrm{jk}$ & 1.811 & .159 & .840 & 11.377 & .000 & .991 & 1.009 \\
\hline
\end{tabular}

Dari tabel 5 dapat disimpulkan bahwa:

1. Varibel equivalent rate memiliki pengaruh yang signifikan terhadap variabel dana pihak ketiga. Hasil pada tabel 4.8 menunjukkan bahwa signifikansi ER sebesar 0,291 terhadap DPK, jika nilai signifikansi ER $>0,05$ maka ER tidak berpengaruh 
Nugraheni, et al/Jurnal Ekonomi Syariah Teori dan Terapan Vol. 4 No. 11 November 2017: 875-888; PENGARUH EQUIVALENT RATE, PROFITABILITAS, DAN JUMLAH KANTOR TERHADAP DANA PIHAK KETIGA BPRS DI INDONESIA (PERIODE TAHUN 2013-2015)

terhadap DPK. Semakin kecil signifikansi varibel ER makan akan semakin berpengaruh terhadap variabel DPK.

2. Variabel Profitabilitas (TP) diperoleh hasil bahwa nilai signifikansi varibel TP adalah sebesar 0,00, dimana niai tersebut $<0,05$. Dari hasil tersebut maka dapat disimpulkan bahwa varibel TP memiliki pengaruh signifikan terhadap varibel DPK.

3. Variabel Jumlah Kantor (JK) diperoleh hasil bahwa nilai signifikansi varibel JK adalah sebesar 0,00, maka dapat disimpulkan bahwa varibel JK memiliki pengaruh yang signifikan terhadap varibel DPK.

\section{Adjusted $\mathbf{R}^{2}$}

Analisis koefisien determinasi dilakukan untuk mengetahui seberapa besar nilai prosentase kontribusi variabel bebas terhadap variabel terikat yang dapat dilihat dalam kolom adjusted $\mathrm{R}^{2}$ pada tabel hasil penelitian.

\section{Tabel 6}

Uji Koefisien Determinasi

\begin{tabular}{l}
\begin{tabular}{l|c|r|r|r|r}
\hline & & & Adjusted R \\
Model & $R$ & R Square & $\begin{array}{c}\text { Std. Error of } \\
\text { Square }\end{array}$ & $\begin{array}{c}\text { Durbin- } \\
\text { Watson }\end{array}$ \\
\hline 1 & $.910^{\circ}$ & .827 & .811 & .05236 & .759 \\
\hline
\end{tabular} \\
\hline
\end{tabular}

Nilai koefisien determinasi pada tabel 6 adalah sebesar 0,811 nilai tersebut menunjukkan bahwa variasi perubahan DPK dipengaruhi oleh perubahan Equivalent Rate (ER), Profitabilitas (TP), dan Jumlah Kantor (JK) sebesar $81,1 \%$. Variabel Equivalent Rate (ER), Profitabilitas (TP), dan Jumlah Kantor (JK) dengan tingkat keyakinan 95\% menerangkan Dana Pihak Ketiga (DPK) sebesar $81,1 \%$, sedangkan sisanya sebesar $13,9 \%$ diterangkan oleh variabel lain diluar penelitian ini.

Pembahasan Pengaruh Equivalent Rate, Tingkat Keuntungan, dan Jumlah Kantor Terhadap DPK BPR Syariah Indonesia

1. Berdasarkan uji yang telah dilakukan, dapat dinyatakan bahwa tidak ada pengaruh yang signifikan antara Equivalent Rate (ER) terhadap Dana Pihak Ketiga (DPK).

2. Berdasarkan uji yang telah dilakukan, dapat dinyatakan bahwa ada pengaruh yang signifikan antara profitabilitas (TP) terhadap Dana Pihak Ketiga (DPK). Dalam penelitian ini variabel Profitabilitas memiliki hubungan yang negatif terhadap variabel Dana Pihak Ketiga. Artinya ketika Profitabilitas BPRS naik, maka Dana Pihak Ketiga pada BPRS juga akan mengalami kenaikan. Hal ini terjadi karena nasabah (masyarakat) menginvestasikan dananya karena faktor kepercayaan, dimana perusahaan ataupun bak dan perbankan syariah dengan profit 
Nugraheni, et al/Jurnal Ekonomi Syariah Teori dan Terapan Vol. 4 No. 11 November 2017: 875-888; PENGARUH EQUIVALENT RATE, PROFITABILITAS, DAN JUMLAH KANTOR TERHADAP DANA PIHAK KETIGA BPRS DI INDONESIA (PERIODE TAHUN 2013-2015)

yang tinggi lebih dipercaya oleh masyarakat.

3. Berdasarkan uji yang telah dilakukan, dapat dinyatakan bahwa jumlah kantor (JK) pengaruh yang signifikan terhadap Dana Pihak Ketiga (DPK). Hal tersebut dikarenakan nasabah Bank Pembiayaan Rakyat Syariah (BPRS) lebih mementingkan faktor lokasi dan layanan yang diberikan oleh BPRS. Calon nasabah BPRS cenderung memilih kantor yang dekat dengan pasar, rumah atau tempat kerja mereka dan tidak memperhatikan besarnya atau luasnya jaringan kantor suatu BPRS. Sehingga, jumlah kantor BPRS tidak berpengaruh signifikan terhadap Dana Pihak Ketiga BPRS tersebut.

4. Dalam penelitian ini membahas faktor internal yang mempengaruhi Dana Pihak Ketiga (DPK) indutri BPRS di Indonesia diantaranya, equivalent rate, profitabilitas, dan jumlah kantor industry BPRS di Indonesia. Berdasarkan uji yang telah dilakukan, dapat dinyatakann bahwa ada pengaruh yang signifikan antara Equivalent rate (ER), profitabilitas (TP), dan Jumlah Kantor (JK) terhadap Dana Pihak Ketiga (DPK). Naik turunnya Dana Pihak Ketiga (DPK) bank pembiayaan rakyat syariah (BPRS) dipengaruhi oleh beberapa faktor, baik faktor eksternal maupun internal. Faktor internal yang mempengaruhi DPK meliputi kinerja keuangan diantaranya equivalent rate dan profitabilitas serta meliputi kualitas layanan seperti jumlah kantor.

\section{SIMPULAN}

Berdasarkan hasil analisis dan pembahasan pada bab sebelum ini, maka dapat disimpulkan sebagai berikut:

1. Equivalent rate, tingkat keuntungan, dan pertumbuhan jumlah kantor secara simultan berpengaruh signifikan terhadap Dana Pihak Ketiga BPR Syariah di Indonesia dengan hasil adjusted $\mathrm{R}^{2}$ sebesar $81,1 \%$. Ini artinya bahwa 81,1\% DPK BPR Syariah pada periode penelitian ini mampu dijelaskan oleh equivalent rate, profitabilitas, dan pertumbuhan jumlah kantor, sedangkan 13,9\% DPK BPR Syariah di Indonesia dijelaskan oleh variabel lain yang tidak diteliti dalam penelitian ini.

2. Equivalent rate secara parsial memiliki hubugan tidak signifikan terhadap Dana Pihak Ketiga BPR Syariah selama periode Januari 2013 sampai dengan Desember 2015.

3. Profitabilitas secara parsial memiliki hubungan positif yang siginifikan terhadap Dana Pihak Ketiga BPR Syariah selama periode Januari 2013 sampai dengan Desember 2015. 
Nugraheni, et al/Jurnal Ekonomi Syariah Teori dan Terapan Vol. 4 No. 11 November 2017: 875-888; PENGARUH EQUIVALENT RATE, PROFITABILITAS, DAN JUMLAH KANTOR TERHADAP DANA PIHAK KETIGA BPRS DI INDONESIA (PERIODE TAHUN 2013-2015)

Dengan demikian maka ketika profitabilitas naik, maka hal ini akan berdampak pada naiknya DPK BPR Syariah di Indonesia.

4. Pertumbuhan Jumlah Kantor secara parsial memiliki hubungan positif signifikan terhadap Dana Pihak Ketiga BPR Syariah selama Januari 2013 sampai dengan Desember 2015. Dengan demikian maka ketika pertumbuhan jumlah kantor naik, maka DPK BPR Syariah di Indonesia pada periode tersebut akan mengalami kenaikan.

\section{Daftar Pustaka}

Antonio, Muhammad Syafi'i. 2001. Bank Syariah dari Teori ke Praktik. Jakarta: Tazkia Cendikia

Apriyani. 2016. BPR Syariah Tumbuh Diatas Rata-rata. (online),

(http://infobanknews.com/bpr-syariahtumbuh-diatas-rata-rata/ diakses pada 30 April 2016)

Arafah, Rahmat. 2015. Faktor Eksternal dan Internal yang Mempengaruhi Pertumbuhan Dana Pihak Ketiga Bank Syariah Indonesia. Skripsi tidak diterbitkan. Surabaya Universitas Airlangga

Arifin, Zainul. 2009. Dasar-dasar Manajemen Bank Syariah. Jakarta: Raja Grafindo Persada

Departemen Agama RI. 2010. Al-Qur'an Tajwid dan Terjemahan. Bandung: CV Diponegoro
Festiani, Setya, dkk. 2013. Perkembangan

BPR Syariah Stagnan, Ini Penyebab Utamanya. (online), (http://www.republika.co.id/berita/eko nomi/syariahekonomi/13/10/30/mvh9ieperkembangan-bpr-syariah-stagnanini-penyebab-utamanya diakses pada 25 April 2016)

Ghozali, Imam. 2011. Aplikasi Analisis Multivariate Dengan Program IBM SPSS 19 (edisi kelima). Semarang: Universitas Diponegoro

Giannini, Nur Gilang. 2013. Faktor-faktor yang Mempengaruhi Pembiayaan Mudharabah pada Bank Umum Syariah di Indonesia. Dalam jurnal Accounting Analysis Journal Vol. 2 No.1, (online), (www.journal.unnes.ac.id diakses pada 21 Agustus 2016)

Gustani. 2016. Ini Dia Daftar Lengkap Bank Syariah di Surabaya. (online), (https://akuntansikeuangan.com/dafta r-lengkap-bank-syariah/ diakses pada 24 Januari 2017)

Karim, Adiwarman Azwar. 2004. Bank Islam: Analisis Figh dan Keuangan. Jakarta: PT Raja Grafindo Persada 2002. Ekonomi Islam Suatu Kajian Makro. Jakarta: The International Institute of Islamic Thought Indonesia Kasmir. 2012. Analisa Laporan Keuangan. Jakarta: Rajawali Pers 
Nugraheni, et al/Jurnal Ekonomi Syariah Teori dan Terapan Vol. 4 No. 11 November 2017: 875-888; PENGARUH EQUIVALENT RATE, PROFITABILITAS, DAN JUMLAH KANTOR TERHADAP DANA PIHAK KETIGA BPRS DI INDONESIA (PERIODE TAHUN 2013-2015)

- 2010. Bank dan Lembaga Kevangan Lainnya. Jakarta: Raja Grafindo Pers

2005. Manajemen Perbankan. Jakarta: Raja Grafindo Persada

Machmud, A., dan Rukmana, 2009. Bank Syariah. Teori, Kebijakan, dan Studi Emperis di Indonesia. Jakarta: Penerbit Erlangga.

Moekijat. 1997. Administrasi Perkantoran. Bandung: Mandar Maju

Muhammad. 2004. Prinsip-prinsip Ekonomi. Jakarta: Graha IImu

Peraturan Pemerintah (PP) No. 72 tahun 1992

Sumitro, Warkum. 2004. Asas-asas Perbankan Islam dan Lembagalembaga Terkait. Jakarta: Raja Grafindo Persada

Sugiyono. 2012. Memahami Penelitian Kuantitatif dan Kualitatif dan R\&B. Bandung: Alfabeta

Susanti, Vera. 2015. Pengaruh Equivalent Rate dan Tingkat Keuntungan Terhadap Dana Pihak Ketiga (DPK) Perbankan Syariah di Indonesia. Dalam jurnal I-Finance Vol. 1. No. 1, (Online), (www.jurnal.radenfatah.ac.id diakses pada 12 April 2016)

Undang Undang Republik Indonesia Nomor 7 Tahun 1992 Tentang Perbankan. Undang Undang Republik Indonesia Nomor 10 Tahun 1998 Tentang Perbankan.
Undang Undang Republik Indonesia Nomor 21 Tahun 2008 Tentang Perbankan Syariah.

Wardani, Elfrida Kusuma. 2015. Pengaruh Tingkat Suku Bunga Bank Indonesia (BI Rate), Indeks Produksi Industri (IPI), dan Jaringan Kantor Bank Syariah Terhadap Penghimpunan Dana Pihak Ketiga Perbanka Syariah di Indonesia. Skripsi tidak diterbitkan. Surabaya, Universitas Airlangga 